\title{
Review Article Adhesion Molecules in Biology and Oncology
}

\author{
Z. LUKÁS̆, K. DVOŘÁK \\ Department of Pathology, Masaryk University Hospital Brno \\ Received July 24, 2003 \\ Accepted December 19, 2003
}

Abstract

Lukáš Z., K. Dvořák: Adhesion Molecules in Biology and Oncology. Acta Vet. Brno, 2004, 73: 93-104.

Adhesion molecules are transmembrane glycoproteins acting as a molecular link between the outside and inside of the cell. They have three domains, the extracellular domain, as a signal receptor from outside, the central domain traversing the cell membrane and the intracellular part transporting signals being attached to the cytoskeletal proteins or to linking molecules-enzymes or similar molecules that can induce a chemical change within the cell, or enter into the nucleus and operate as transcription factors.

The adhesion molecules are involved in the cell differentiation, migration and sorting. The most direct effect of cell-cell adhesion is on morphogenesis, that is, on the assembly of individual cells into highly ordered tissues and organs. This is characterised by sequential expression of cell adhesion molecules on the surface of embryonic cells. For example, E cadherin is one of the first adhesion molecules that human express, essential for early organisation of the developing embryo. Neoplasia or cancer is viewed as a cell cycle disease. Although this concept implies that every tumor is defective in one or more aspects of the cell cycle control, it clearly does not mean that oncogenesis targets only oncogenes and the cell cycle clock. Development of malignancy appears to require also aberrations in the cell death machinery and cell-cell and/or cell-matrix interactions that cooperate with cell cycle defects. Many of the processes in which adhesion molecules play central role - anchorage dependent growth, apoptosis, differentiation, and migration are those that are characteristically dysregulated in malignancy.

Adhesion, signalling, differentiation, neoplasia

Adhesion molecules (AM) are involved in many fundamental processes of the cell. They are closely associated with cytoskeletal filaments and signal molecules in the cell and with AM of the basement membrane, extracellular matrix (ECM) or adjacent cells.

AM are transmembrane glycoproteins acting as a molecular link between the outside and inside of the cell. They have three domains: the extra-cellular domain bound to the ECM or adjacent cell membrane, acts as a signal receptor from outside. The central domain traverses the cell membrane and the intracellular part transports signals being attached to various ligands - cytoskeletal proteins, enzymes or similar molecules that can link to metabolic pathways within the cell, or to transcription factors. The complex ligand - transcription factor ( $\beta \mathrm{C}$ and LEF-1 in Fig. 1) may enter into the nucleus and bind to DNA (Freemont 1998).

There are several families of AM: (a) Immunoglobulin-like superfamily, (b) Cadherins, (c) Integrins, (d) Receptor protein tyrosine phosphatases (RPTP), (e) Selectins, (f) Hyaluronate receptors and (g) Dipeptidyl peptidase IV (CD26).

Immunoglobulin-like superfamily

The immunoglobulin (Ig) - like large family of adhesion molecules have components that resemble Ig. The group includes molecules involved in antigen recognition by lymphocytes and other cells (CD3, CD4, CD8). E.g. HIV binds to T cells through CD4

Address for correspondence:

Prof. MUDr. Z. Lukáš, CSc.

Department of Pathology

Jihlavská 20, 63900 Brno, Czech Republic 
adhesion molecule. Other subgroups mediate cell adhesion for a variety of different cell types (Table 1).

Table 1

Immunoglobulin-like adhesion molecules

\begin{tabular}{|c|c|c|}
\hline Adhesion molecule & Expressed on & Ligand \\
\hline ICAM 1, ICAM 2 & Epithelium, endothelium & Leukocyte integrins \\
\hline VCAM & Endothelium & $\begin{array}{l}\alpha 4 \beta 1 \text { integrin on monocytes and } \\
\text { lymphocytes }\end{array}$ \\
\hline PECAM (CD 31) & Leukocytes, endothelium & $\alpha \mathrm{V} \beta 3$ integrin \\
\hline BL CAM (CD22) & Differentiating B cells & \\
\hline IAP (CD47) & $\begin{array}{l}\text { Endothelium, leukocytes, } \\
\text { fibroblasts, epithelium, } \\
\text { erythrocytes, neurons }\end{array}$ & $\alpha \mathrm{V} \beta 3$ integrin \\
\hline MAdCAM & Mucous membrane & $\begin{array}{l}\alpha 4 \beta 7 \text { integrin, } L \text { selectin on } \\
\text { Peyer's patch lymphocytes }\end{array}$ \\
\hline
\end{tabular}

Adhesion molecules ICAM-1 and ICAM-2 are expressed on epithelial and endothelial cells and recognized by leukocyte integrins. Vascular adhesion molecule VCAM-1 is a ligand for $\alpha 4 \beta 1$ integrin on monocytes and lymphocytes, and mucosal addressin CAM (MAdCAM) is recognized by $\alpha 4 \beta 7$ integrin and L-selectin on Peyer's patch lymphocytes. Two immunoglobulin superfamily members involved in leukocyte trans-endothelial migration are platelet endothelial adhesion molecule (PECAM) and integrin-associated protein (IAP). PECAM is expressed at endothelial cell-cell junctions and on all leukocytes, IAP is present on fibroblasts, platelets, erythrocytes, neurones, epithelium, endothelium and leukocytes (Kerr 1999). The CD22 antigen appears early in the B cell lymphocyte differentiation. The immunoglobulin superfamily members are also involved in other fields, e.g. development of the nervous system and regulation of the immune system.

\section{Cadherins}

Calcium-dependent cell adhesion molecules have both adhesion and calcium binding sites on the extracellular domain. They bind to other cadherins on the surface of adjacent cells. Their cytoplasmic domain binds to catenins, $\alpha$ and $\beta$, and plakoglobin (PLG, $\gamma$-catenin), which in turn attach to cytoskeletal filaments or other molecules. The best characterised cadherin - E cadherin - is a molecule whose expression is regulated by the ErbB2protooncogen. E cadherin is con-

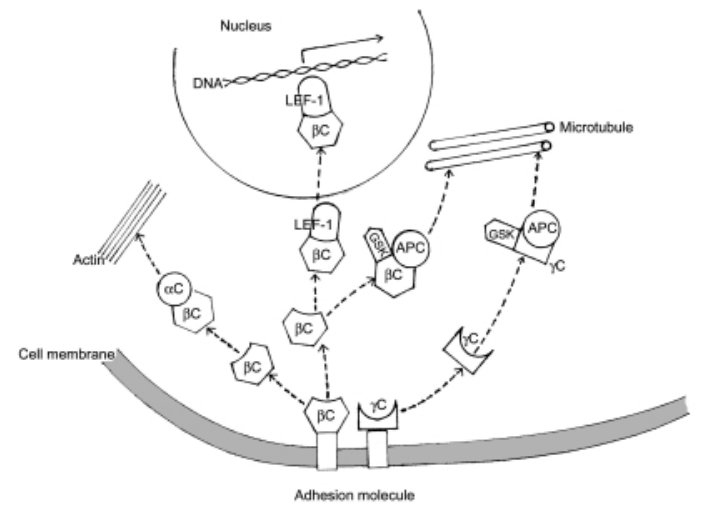

Fig. 1. E-cadherin (transmembrane rectangles) and catenins (C, C and C-plakoglobin) as adhesion and signalling molecules. APC - adenomatous polyposis coli protein, GSK - glycoprotein synthase-kinase-3, LEF-1 transcription factor. 
centrated in an intercellular junction, where it attaches to actin through catenins (Fig. 1). The binding of the transmembranous E-cadherin molecule and the actin cytoskeleton is essential for the formation of strong cell-cell adhesion. The major desmosomal glycoproteins, the desmocollins and desmogleins, are members of the cadherin super-family. Three desmocollin isoforms (Dsc 1, 2 and 3) and three desmoglein isoforms ( $\mathrm{Dgl} \mathrm{1,2,3)}$ are products of a distinct gene (Garrod et al 1996). Desmosomal proteins show graded distribution in epidermis (Fig. 2). Autoantibodies to Dsg 1, Dsg 3 and Dsc 1 are involved in the pemphigus foliaceus, pemphigus vulgaris and $\operatorname{IgA}$ pemphigus, respectively. Complement induced damage causes the desmosomal breakdown, separation of keratinocytes and formation of an intraepidermal blister.

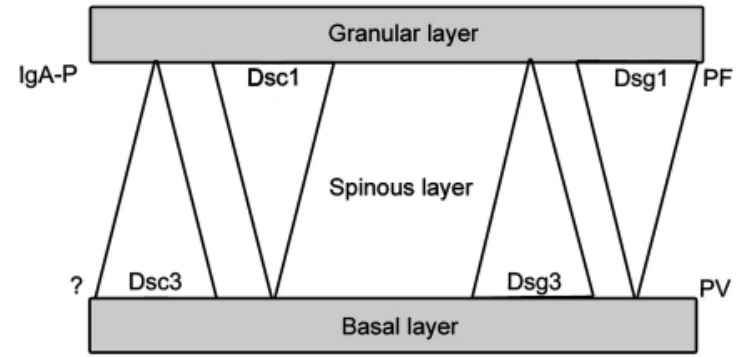

Fig. 2. Graded distribution of desmosomal glycoproteins in epidermis: expression of Dsc3 and Dsg3 decreases from basal to surface layers, whereas expression of Dsc1 and Dsg 1 shows a reciprocal pattern.

Association of cadherins with catenins modulates the level of free $\beta$ catenin or PLG in the cytoplasm and ability of them to interact with APC (adenomatous polyposis coli) tumour suppressor molecule or with transcription factors such as LEF-1 (Fig. 1). The complex of LEF1 and $\beta$-catenin or LEF-1 and PLG can translocate into the nucleus and directly bind to the 5 ' end of the E-cadherin gene and/or other genes to regulate their expression. The association between $\beta$-catenin or PLG and APC downregulates free $\beta$-catenin levels as well as linkage with glycoprotein synthase kinase-3 $\beta \quad(G S K-3 \quad \beta) \quad(N a ̈ t h k e \quad 1999) . \quad \beta$-catenin, a structural component of adhesion sites, can sometimes also double as a transcription factor in the nucleus. This occurs normally in particular developmental contexts and abnormally in cancer cells, where beta-catenin becomes deregulated owing to mutation events. Induction of p53 (Fig. 3) takes place via tumor suppressor ARF and mdm-2 proteins (Oren et al. 2002).

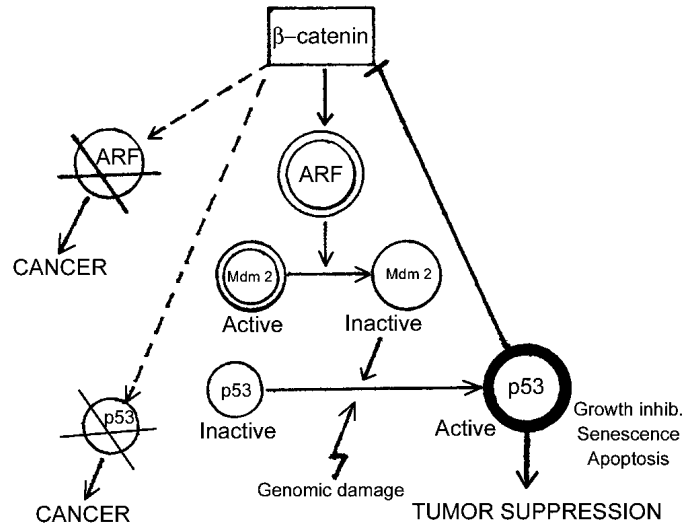

Fig. 3. The p53 - -catenin loop. Deregulated -catenin induces the expression of the ARF tumor suppressor protein, which binds and inactivates Mdm2. This results in the accumulation of p53 protein. If this inhibitory pathway is defective (dysfunction of p53 or ARF), -catenin promotes cancer. 
Phosphorylation of the cadherin complex is regulated by members of the Ras family. Key regulators of cadherin-mediated adhesiveness were identified as proteins of the small GTPases whose function is dependent on the type of nucleotide bound (B rag a 1999). Inside the cell, members of the Ras family are normally associated with GDP in an inactivated state. Activation is brought about by binding to GTP, a process that is modulated by the GEF (guanin exchange factor) and GAP (GTPase activation protein) regulatory proteins (Fig. 4)

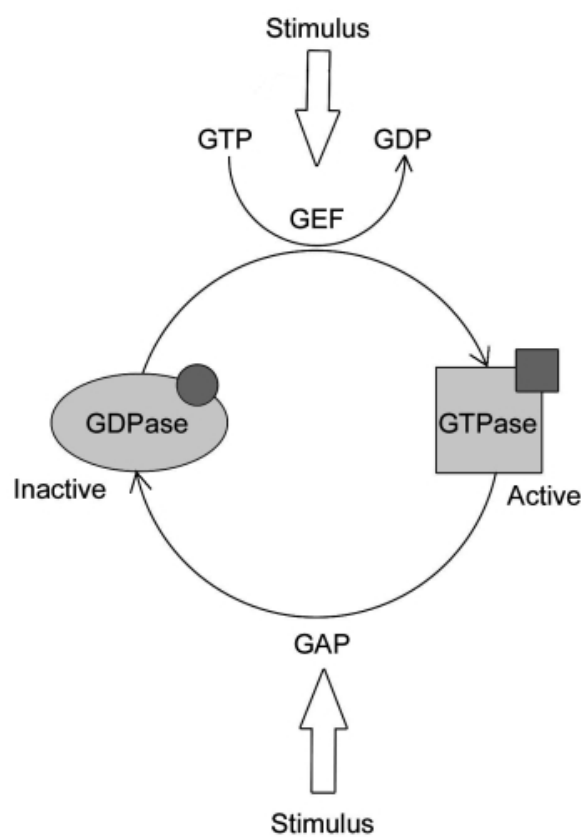

Fig. 4. GTPase - GDPase transactivation modulated by GEF and GAP. Activation brought about by binding GTPase to GTP

\section{Integrins}

Integrin adhesion molecules are heterodimers, each integrin consists of one $\alpha$ and one $\beta$ component. Most integrins function as receptors for ECM proteins; however, some family members, such as the $\beta 2$ integrins and $\alpha 4 \beta 1$ integrin mediate heterotypic cell-cell adhesion.

The integrins can be subclassified according to the beta subunits involved in the complex. The $\beta 1$ and $\beta 3$ subfamilies are involved predominantly in interaction between cells and their matrices, while the members of the $\beta 2$ class are the cell-cell adhesion molecules expressed on leukocytes. The $\beta 1$ integrins are involved in adhesion to connective tissue macromolecules such as fibronectin, laminin and collagens, whereas the $\beta 3$ integrins bind to vascular ligands such as fibrinogen, von Willebrand factor, thrombospondin and vitronectin. Some of the integrins are highly specific in their ligand binding properties recognising short amino-acid sequences on matrix proteins and cell surfaces. Thus, $\alpha 5 \beta 1$ integrin binds to a tetrapeptide arginine-glycine-aspartate-serine (RGDS) motif on fibronectin, whereas $\alpha 2 \beta 1$ binds to amino acid sequences on collagen, fibronectin and laminin.

The $\beta$ chain cytoplasmic domains interact with the actin cytoskeleton via a range of proteins such as $\alpha$-actinin, talin, vinculin, and tensin (Jones and Walker 1999).

The $\beta 4$ subunit - a major component of hemidesmosomes, has a large cytoplasmic domain which interacts with the intermediate filaments. In bulous pemphigoid, antibodies against a hemi-desmosome component of the keratinocytes, bullous pemphigoid antigen 1 (BPAG 1); 
are present in the serum. Adhesion receptors in the lamina lucida of the basement membrane (BM) are BPAG 2 and $\alpha 6 \beta 4$ integrin (Fig. 5). Damage to the hemi-desmosome leads to failure of adhesion between the epidermis and its BM with the formation of subepidermal blisters.

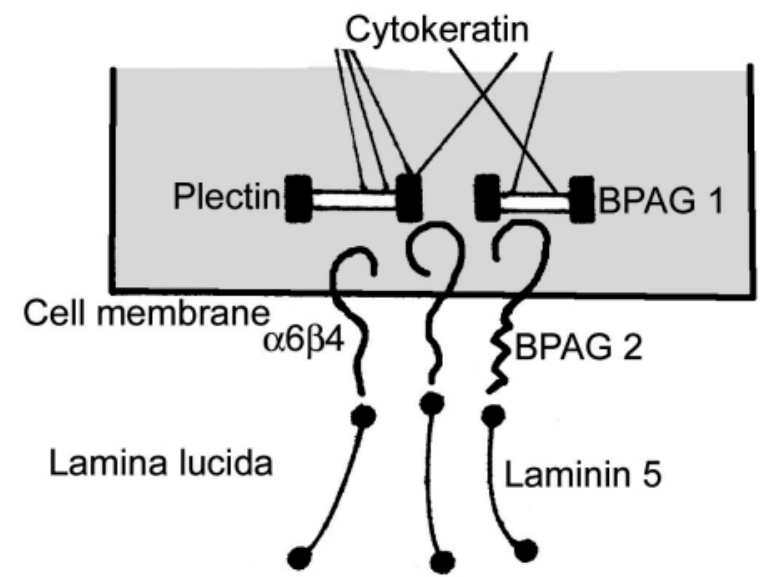

Fig. 5. Hemidesmosome. BPAG 1- the hemi-desmosome component, BPAG 2 and 64 integrin as adhesion receptors.

The integrin and integrin-associated structure organisation is governed (like the cadherincatenin system) by members of the Ras or Rho family of GTP-ases. Signalling leading to the activation of integrins may come from both outside and inside. "Outside in" signalling mediates signals from the extracellular matrix after integrin ligation. It involves ligation and clustering of integrins with subsequent assembly of the focal adhesion plaque, a complex of cytoskeletal proteins and signalling molecules including vinculin, talin, paxilin, alfa-actinin, tensin and a cytoplasmic tyrosine kinase, focal adhesion kinase, (FAK). Activation and autophosphorylation of FAK and its recruitment to focal adhesions is the key step in adhesion-mediated signalling. Phosphorylated FAK can lead to activation of another tyrosine kinase, the mitogen activated protein kinase (MAPK) pathway, probably via Ras activation (Fig. 6), which can then influence gene expression (Jones and Walker 1999).

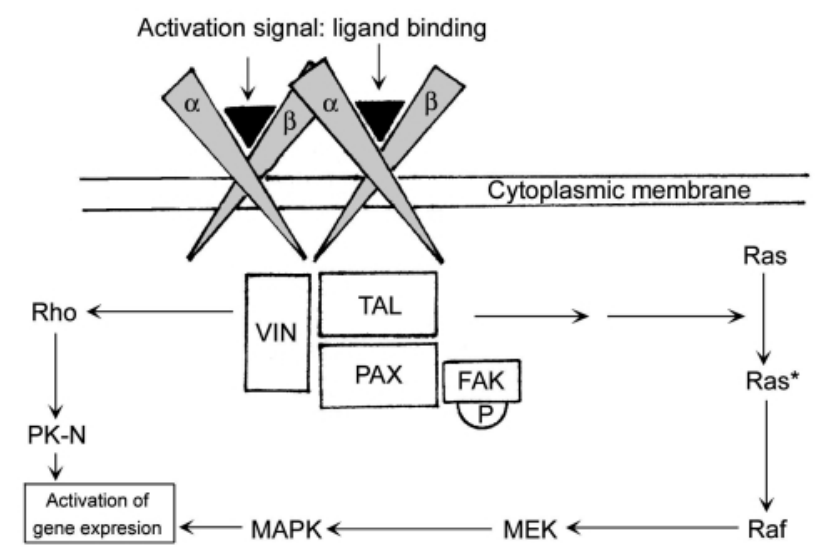

Fig. 6. Integrin signalling outside - in. Extracellular integrin ligands - black triangles, intracellular ligands VIN vinculin, TAL - talin and PAX - paxillin. MEK - kinase-kinase, MAPK - mitogen activated protein kinase 
"Inside-out" signalling is the mechanism by which a cell regulates the affinity state of its integrin receptors. It involves the propagation of conformational changes from the cytoplasmic domains of integrins to the extracellular binding sites in response to intracellular signalling events (Fig. 7). The signalling may occur by Rho dependent reorganisation of the cytoskeleton and/or by changes of phosphorylation of integrin cytoplasmic domains (Jones and Walker 1999) or integrin associated proteins.

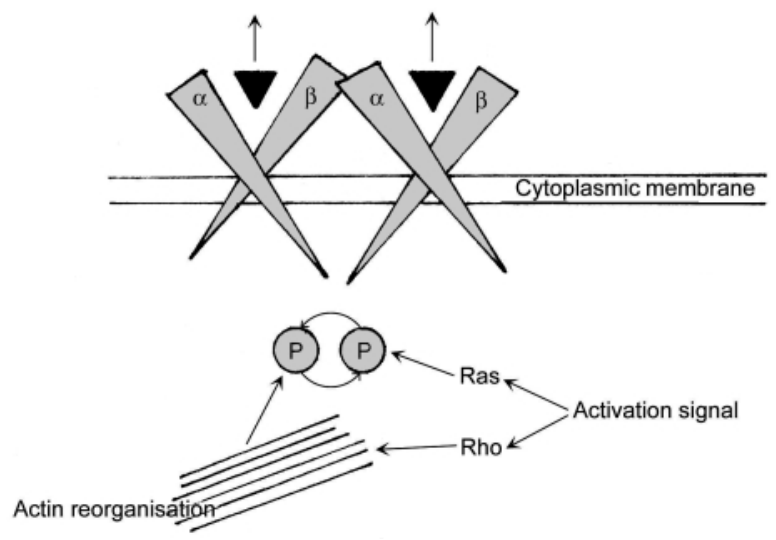

Fig. 7. Integrin signalling inside - out leads to disengagement of the extracellular ligands

The above-mentioned pathways are called direct signalling. In collaborative signalling, integrin-mediated cell adhesion modulates signalling initiated through other types of receptors, e.g. receptor tyrosine kinases or CD44.

Integrin mediated anchorage is also a key regulator of anoikis, programmed cell death (apoptosis) caused by loss of anchorage. Normal cells are dependent on anchorage not only for growth, but also for survival. In contrast to normal cells, transformed cells are characterised by their anchorage-independent growth.

\section{Receptor Protein Tyrosin-Phosphatases (RPTP)}

Receptor Protein Tyrosin-Phosphatases (RPTP) are involved in intracellular signalling and regulation of cell-cell adhesion. While other cell adhesion molecules need another molecule to link to enzymes within the cytoplasm to influence intracellular events, the RPTPs have a functional cytoplasmic domain that resembles and works as tyrosin phosphatase. In this way, they have the potential to modulate intracellular events directly (Freemont 1998).

\section{Selectins}

Selectins have lectin-like carbohydrate binding domain on the extracellular part of the molecule. There are three main groups of selectins: L selectins, (CD62L), important for leukocyte homing to particular tissues on vascular endothelium, E-selectins (CD62E), endothelial leukocyte adhesion molecules, important mediators of inflammatory reactions, and P-selectin, (CD62P), contained in Weibel-Palade bodies of endothelial cells and $\alpha$ granules of platelets. This is released during blood clotting and at time of platelet activation, mediating adhesion between leukocytes and platelets (Freemont 1998). 


\section{Hyaluronate receptors}

This group has received increased interest, because hyaluronate (HA) receptors are involved in growth, differentiation and tumour progression. HA is a linear polymeric glycosaminoglycan, an ubiquitous component of the extra-cellular matrix (ECM). Cells bind to HA ligand of the ECM through cell surface receptor proteins of which the best characterised is CD44 (Fig. 8). CD44 exhibits molecular variations (CD44v-s) through the

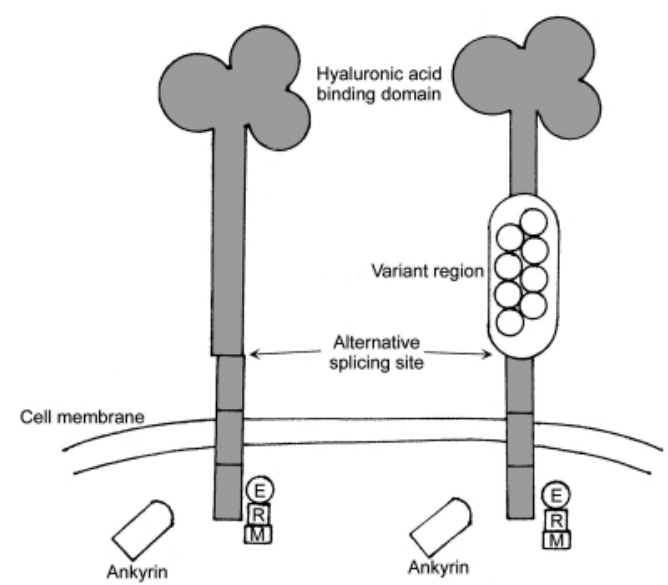

Fig. 8. Domains of CD 44 molecule. Intracellular CD44 ligands: E - ezrin, R- radixin, M - moesin

process known as alternative splicing, which influences the way in which mRNA is made from DNA. The human CD44 gene has been mapped to the locus $11 \mathrm{p} 13$ and is composed of two groups of exons (Goodis on et al. 1999). One group, exons 1-5 and 16-20 are spliced together to form a transcript that encodes the ubiquitously expressed standard isoform (CD44s). The 10 variable exons 6-15 (also known as v 1-10 ) can be alternatively spliced and included within the standard exons at an insertion site between exons 5 and 16 (Fig. 9).

Standard exons

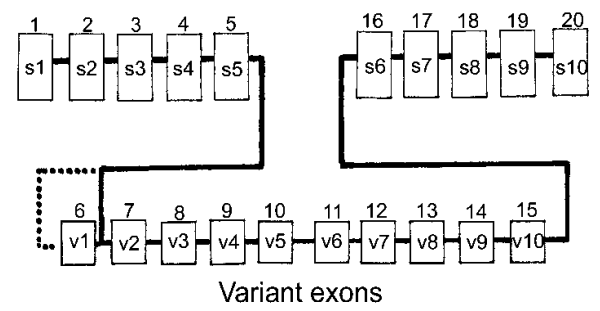

Fig. 9. Standard and variant exons of CD44 gene (splicing)

Molecules containing the variable exons or their peptide products are designated CD44v and, in theory, alternative splicing would allow more than 1000 different CD44 variants. The most abundant standard form of human CD44 protein (CD44s) contains 363 amino acids and has a theoretical molecular mass of $37 \mathrm{kDa}$. Interaction of CD 44 with cellular proteins includes multimerisation of CD44. Ligand binding may be enhanced by CD44 clustering. CD44 interacts with the HER2 (c-ErbB2) cell surface protein, a tyrosine kinase and a member of the EGF receptor family. Both CD44 and HER2are found on the cell surface linked to each other via interchain disulphide bonds. Overexpression of HER 2 by tumour cells is associated with a poor prognosis in many studies of breast and ovarian cancers. 
The cytoplasmic domain has been shown to bind a number of intracellular proteins. Cytoskeleton is bound to CD44 by the ERM (ezrin, radixin, moesin) family. In haemopoetic cells, it has been shown that the protein 4.1 can bind directly to CD44 and this interaction prevents subsequent ankyrin binding. Detection of CD44v-s is important for assessment of biological properties of tumours.

\section{CD26 - Dipeptidyl-peptidase IV.}

CD26 or dipeptidyl-peptidase IV (DPP IV), is a transmembrane protein with cytoplasmic tail containing 6 amino acids followed by a 22-aminoacid trans-membrane domain at the $\mathrm{N}$ terminus and a stretch of 200 amino acids at the $\mathrm{C}$ terminus that constitutes a catalytic centre. Tissue repair requires a remodeling of the ECM by migratory cells. CD26 hydrolyses the carboxy-terminal side of dipeptide sequences, and may be involved in the cleavage of collagen and fibronectin. CD26 has an essential role in immune regulation as a T cell activation molecule and a regulator of cytokine function.

\section{Function of cell adhesion molecules in development, motility and migration}

The adhesion molecules are involved in the cell differentiation, migration and sorting. The most direct effect of cell-cell adhesion is on morphogenesis, that is, on the assembly of individual cells into highly ordered tissues and organs. Sequential expression of cell adhesion molecules on the surface of embryonic cells is essential for early organisation of the developing embryo. E-cadherin is one of the first adhesion molecules that human express. Cadherins regulate a variety of early events, such as the interactions between ectoderm and mesoderm that lead to formation of the neural plate. T cadherin is absent from muscle cells during early development and is upregulated once innervation has occurred and synapses formed. N cadherin anchors the nerve to the synaptic site. CD44 takes place in the developement of the limb: antibodies to CD44 block cartilage formation.

Cell adhesion molecules play important role in controlling cell migration through their connections with cytoskeleton. It was mentioned that cadherins associate with catenins which are attached to contractile molecules such as actin (Fig. 1). Cell motility across a matrix is regulated through cell attachment and detachment mediated through a cell adhesion molecules. Cells extend cytoplasmic protrusions called invadopodia, that become tightly adherent at its tip. For this to occur, cells need to cause migration and aggregation of cell adhesion molecules within their cell membranes (Fig. 10). The $\alpha 3 \beta 1$ and $\alpha 5 \beta 1$ integrins play major organisation roles in the adhesion and formation of invadopodia

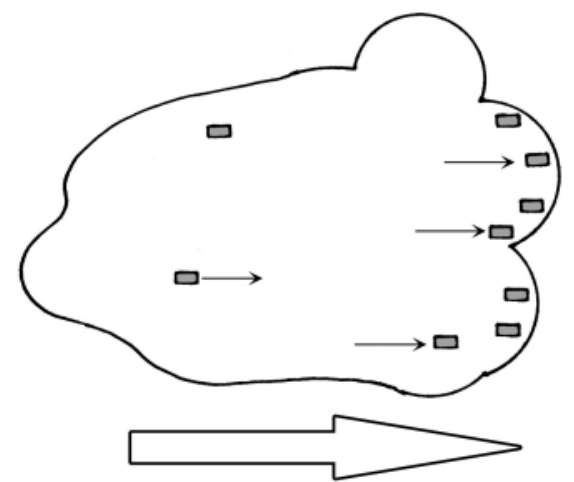

Fig. 10. Adhesion molecules (small rectangles) translocation in directed (white arrow) cell motility 
promoting invasive cell behaviour (Mueller et al. 1999). Cell surface proteases (e.g. CD26) also play an important role in facilitating cell invasion into the ECM (Chen 1996). $\alpha \mathrm{V} \beta 3$ integrins has been shown to modulate ECM proteolytic activity by recruiting a major soluble proteinase, matrix metallo-proteinase-2 (MMP-2), to the cell surface.

\section{Proliferation, neoplasia, malignancy}

Abnormal cellular growth is one of the hallmarks of tumors. It is known that defects in some of molecules that regulate the cellular proliferation machinery are common in tumor cells. Neoplasia or cancer is viewed as a cell cycle disease. Although this concept implies that every tumor is defective in one or more aspects of the cell cycle control, it clearly does not mean that oncogenesis targets only the cell cycle clock. Changes in the pattern of expression of a cell adhesion molecule in a tissue are likely to disrupt normal epithelial-mesenchymal interaction and can contribute to structural and functional disorganisation, a characteristic of cancer. Development of malignancy appears to require also aberrations in the cell death machinery and cell-cell and/or cell-matrix interactions that cooperate with cell cycle defects (Bártek et al. 1999). The elucidation of the signal transduction pathways that regulate cell growth and differentiation has led to a number of opportunities for novel cancer therapy.

The member of the Ig-like family, CD22 antigen (BL CAM) is weakly expressed on myeloid leukemias and non-T cell acute lymphoblastic leukemias and is strongly expressed on hairy cell leukemias. The CD 31 antigen is involved in interactive events during angiogenesis and wound healing. Endothelial labelling for CD31 antigen may be one of the most reliable methods for determining vascular invasion in cases of breast cancer.

Reduction of cell adhesion is of major importance in tumor metastasis and can be achieved by a variety of mechanisms affecting the E-cadherin-catenin complex. These include reduction or loss of E-cadherin expression, mutation of the genes of constituent molecules, redistribution of E-cadherin within the cell shedding of E-cadherin etc. It is possible that hypoxia takes part in the down- regulation of E-cadherin expression and the initiation of metastatic cascade of neoplasms (Beavon 1999). Reduction or loss of E-cadherin expression has been found in numerous tumours from varying organs including colon, stomach, pancreas, oesophagus, liver, lung, bladder, prostate, skin, breast, uterus and ovary carcinomas. The degree of tumour differentiation appears to be related to the proportion of E-cadherin expression. Reduced Ecadherin expression in poorly differentiated tumours may be result of downregulation or defects in the catenins. A good correlation exists between the loss of E cadherin expression and the acquisition of the undifferentiated state.

Deregulated beta-catenin stimulates transcription of the tumor suppressor protein ARF ( $\mathrm{p} 14^{\mathrm{ARF}}$ in human cells) mRNA, leading to inhibition of $\mathrm{Mdm} 2$ and consequent accumulation of active wt p53. In this way, coupling between $\beta$-catenin and p53 serves as an anticancer mechanism. In cells where this inhibitory pathway is is defective, owing to dysfunction of either ARF or p53 itself, $\beta$-catenin is free to exert his oncogenic effects and to promote cancer. The activated p53 when present in sufficiently high levels, can drive the proteosomal degradation of beta-catenin. This inhibitory arm of the loop is abolished when p53 undergoes direct mutational inactivation (Fig. 5). Activating mutations in exon 3 of the $\beta$-catenin gene have been described in many human malignancies, in sporadic colorectal adenomas and in the fundic gland polyps (Chang et al. 2002).

Many of the processes in which integrins play central role - anchorage dependent growth, apoptosis, differentiation, and migration are those that are characteristically dysregulated in malignancy. Some of them exhibit altered expression of integrin or integrin receptors in comparison with their normal counterparts. The collagen receptor $\alpha 2 \beta 1$ is more strongly expressed in invasive melanoma compared with in situ melanoma. 
Resistance to apoptosis is a feature of many malignant cells and such resistance may be the result of aberant integrin signalling. E.g. in rhabdomyosarcoma, downregulation of integrin associated FAK induces apoptosis in these cells, whereas cells that overexpress FAK are rescued from apoptosis.

Integrins also contribute to cellular migration and metastasis. Antagonists to $\alpha \mathrm{v} \beta 3$ integrin (the vitronectin receptor expressed by vascular cells) promote tumour regression by inducing apoptosis of angiogenic blood vessels that are necessary for tumour development.

Another important aspect of invasion is proteolytic remodeling of the stroma by enzymes such as matrix metallo-proteinases (MMPs). In rabbit synovial fibroblasts, $\alpha 4 \beta 1$ integrin and $\alpha 5 \beta 1$ integrins differentially regulate the production of MMPs. In human melanoma cell lines, $\alpha 5 \beta 1$ integrin and $\alpha \mathrm{V} \beta 3$ integrin modulates release of MMP-2 and subsequent invasive behaviour.

Early studies identified changes in the organisation of the cytoskeleton and junctional proteins of cancer cells. Restoration of vinculin and $\alpha$-actinin expression in tumor cells results in the suppression of the tumorigenic and metastatic ability of such cells. As overexpression of vinculin causes the assembly of larger focal adhesions and inhibits cell motility, while elimination of vinculin results in enhanced motility and reduced adhesion and spreading, these changes in cell morphology, adhesion and motility can be viewed as the cause, rather than the effect, of malignant transformation (Ben-Ze' ev 1997).

Selectins are involved in neoplasia as well. Potential endothelial ligands for L-selectin may be seen on venules in a high proportion of cutaneous lymphomas suggesting that they might be involved in the spread of these lymphomas. The expression of carbohydrate determinants for E selectin binding is related to the metastatic potential of colon carcinoma cells. Similarly, $P$ selectin on endothelial cells could also be involved in the metastatic arrest of tumour cells bearing appropriate carbohydrate epitopes.

The expression of multiple CD44 isoforms and the resulting HA binding profile can influence tumor growth and development. It was shown that tumour tissues contain a number of unusual CD44 transcripts relative to those present in corresponding normal tissues. Much effort was devoted to the possible involvement of CD44 isoforms in tumour metastasis. Several investigations provided evidence of a correlation between raised CD44 expression and metastatic capacity in cultured human melanoma and lymphoma cell lines. In these reports, however, it was CD44s rather than CD44v isoforms that were associated with metastatic behaviour. In colonic and breast cancers a direct relation has been described between the CD44 isoform and metastatic potential.

There are many studies of CD44 expression in human neoplasms. In the most aggressive tumours, up to $100 \%$ of cases expressed the CD44v, whereas the equivalent corresponding epithelial cells did not express the molecule. CD44 expression in breast carcinomas can be regulated by hormones. Increases in the expression of oestrogen and progesterone receptors showed a positive correlation with CD44v6.

In addition to function as an ECM adhesion molecule, DPP IV expression is involved in the pathogenesis of selected human cancers (Dang and Morimoto 2002). The expression of CD 26 has been found in $93 \%$ of lung adenocarcinomas, whereas all cases of squamous cell carcinoma, small cell carcinoma, large cell carcinoma and carcinoid have been negative. T chronic lymphocytic leukaemias with CD3+, CD4+, and CD8- phenotype revealed CD26 positivity in T cells. DPP IV is also a marker of thyroid neoplasia. Papillary carcinoma samples did not show any gene amplification or major translocation: the positivity is caused by overexpression of CD26 mRNA (Tanaka et al. 1996). Histochemical expression of CD26 in thyroid neoplasia may be considered a reliable marker of the biological behaviour in well differentiated papillary and follicular carcinomas (Kholová et al. 2002). DPP can mediate the adhesion of circulating breast cancer cells to pulmonary endothelia during experimental metastasis (Chen 1996). 


\section{Adhezní molekuly v biologii a onkologii}

Adhezní molekuly jsou transmembránové glykoproteiny fungující jako molekulární spojka mezi nitrem buňky a jejím okolím. Mají tři domény: extracelulární, působící jako př́ijemce signálů zvenčí, střední, křižující buněčnou membránu, a intracelulární, která přenáší signály do buňky a je napojená na cytoskeletální proteiny nebo na vazebné molekuly či enzymy. Tyto mohou indukovat chemické změny v buňce nebo i vstoupit do jádra a působit jako transkripční faktory.

Adhezní molekuly se účastní buněčné diferenciace, migrace a třídění. Nejvýraznějším projevem mezibuněčných adhezí je morfogeneze, seskupování jednotlivých buněk do výše uspořádaných tkání a orgánů. To se uskutečňuje následnou expresí adhezních molekul na povrchu embryonálních buněk. První adhezní molekulou, kterou lidský organismus exprimuje je E kadherin, potřebný pro časnou organizaci vyvíjejícího se embrya.

Neoplasie je pokládána za poruchu buněčného cyklu. I když tento koncept předpokládá, že každý nádor má určitý defekt $\mathrm{v}$ některém ze článků kontroly buněčného cyklu, neznamená to, že onkogeneze se týká jen onkogenů a časování buněčného cyklu. Vývoj malignity zřejmě rovněž vyžaduje aberace $v$ mechanismech buněčné smrti, i v poruše vzájemných interakcí mezi buňkami a mezi buňkou a extracelulární matrix. Také tyto se účastní alterací buněčného cyklu. Mnohé procesy, v nichž adhezní molekuly hrají rozhodující úlohu - růst závisející na zakotvení buňky, apoptóza, diferenciace a migrace jsou procesy charakteristicky deregulované při rozvoji malignity.

\section{Acknowledgement}

This paper was financially supported by the grants of the Ministry of Health MZ 00065269705 and NC 6771-3.

\section{References}

BARTEK, J, LUKAS, J, BARTKOVA, J 1999: Perspective: defects in cell cycle control and cancer. J Pathol 187: 95-99

BEAVON, IRG 1999: Regulation of E-cadherin: does hypoxia initiate the metastatic cascade? J Clin Pathol: Mol Pathol 52: 179-188

BEN ZE'EV, A 1997: Cytoskeletal and adhesion proteins as tumor suppressors. Curr Opin Cell Biol 9: 99-108

BRAGA, VMM 1999: Small GTPases and regulation of cadherin dependent cell-cell adhesion. J Clin Pathol: Mol Pathol 52: 197-202

BURGESON, RE, CHRISTIANO, AM 1997: The dermal-epidermal junction. Curr Opin Cell Biol 9: 651-658

CHANG, HJ, JEE, CD, KIM, WH 2002: Mutation and altered expression of $\beta$-catenin during gallbladder carcinogenesis. Am J Surg Pathol 26: 758-766

CHEN WT 1996: Proteases associated with invadopodia and their role in degradation of extracellular matrix. Enzyme Protein 49: 59-71

FREEMONT, AJ 1998: Adhesion molecules. J Clin Pathol: Mol Pathol 51: 175-184

GADBOIS, DM, BRADBURY, EM, LEHNERT, BE 1997: Control of radiation-induced G1 arrest by cellsubstratum interactions. Cancer Res 57: 1151-1156

GARROD, D, CHIDGEY, M, NORTH, A 1996: Desmosomes: differentiation, development, dynamics and disease. Curr Opin Cell Biol 8: 670-678

GOODISON, S, URQUIDI, V, TARIN, D 1999: CD44 cell adhesion molecules. J Clin Pathol: Mol Pathol 52: 189-196

HOWE, A, APLIN, AE, ALAHARI, SK, JULIANO, RL 1998: Integrin signaling and growth control. Curr Opin Cell Biol 10: 220-231

JONES, JL, WALKER, RA 1999: Integrins: a role as signalling molecules. J Clin Pathol: Mol Pathol 52:208-213 KERR, JR 1999: Cell adhesion molecules in the pathogenesis of and host defence against microbial infection. J Clin Pathol: Mol Pathol 52:220-230

KHOLOVÁ, I, LUDVÍKOVÁ, M, RYŠKA, A, ČÁP, J 2002: Dipeptidyl aminopeptidase IV in differential diagnosis of thyroid tumors: description of method and results of pilot study (in Czech). Čes-slov Patol 38:11-17

MUELLER, SC, GHERSI, G, AKIYAMA, SK, SANG, QXA, HOWARD, L, PINEIRO-SANCHEZ, M, NAKAHARA, H, YEH, Y, CHEN, WT 1999: A novel protease-docking function of integrin at invadopodia. J Biol Chem 35: 24947-24952

NÄTHKE, IS 1999: The adenomatous polyposis coli protein. J Clin Pathol: Mol Pathol 52: 208-213 
104

NIGRO, JM, ALDAPE, KD, HESS, SM, TISTY, TD 1997: Cellular adhesion regulates protein levels in primary human keratinocytes. Cancer Res1997 57: 3635-3639

OREN, M, DAMALAS, A, GOTTLIEB, T, MICHAEL, D, TAPLICK, J, LEAL, JFM, MAYA, R, MOAS, M, SEGER, R, TAYA, Y, BEN-ZE'EV, A 2002: Regulation of p53 - Intricate loops and delicate balances. Ann NY Acad Sci 973: 374-383

SNEATH, RJS, MANGHAM, DC 1998: The normal structure and function of CD44 and its role in neoplasia. J Clin Pathol: Mol Pathol 51: 191-200

TANAKA, T, UMEKI, K, YAMAMOTO, I, ARATAKE, Y, SAKAMOTO, F, NOGUCHI, S, OHTAKI, S 1995: CD26 (dipeptidyl- peptidase-IV/DPP-IV) as a novel molecular marker for differentiated thyroid-carcinoma. Int J Cancer 64: 326-331

VAHERI, A, CARPEN, O, HEISKA, L, HELANDER, TS, JAASKELAINEN, J, MAJANDER-NORDESWAN, P, SAINIO, M, TIMONEN, T, TURUNEN, O 1997: The ezrin protein family: membrane-cytoskeleton interactions and disease associations. Curr Opin Cell Biol 9: 659-666

VARNER, JA, CHERESH, DA 1996: Integrins and cancer. Curr Opin Cell Biol 8: 724-730 